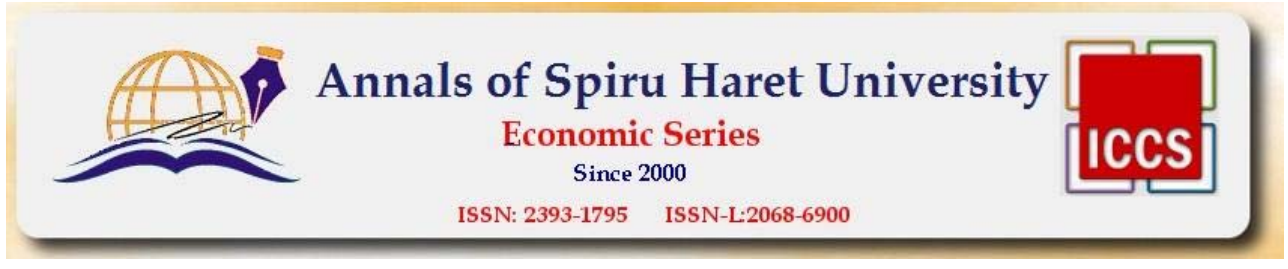

Issue $3 / 2017$

\title{
THE RISK IN TOURISM - TERRORISM, A THREAT FOR EUROPEAN TOURISM
}

\author{
Bogdan SOFRONOV ${ }^{1}$ \\ ${ }^{1}$ University Politehnica of Bucharest, Splaiul Independenței 313, Bucharest \\ 060042, Romania,Email: boghy.official@yahoo.com
}

\begin{abstract}
The paper presents information about risk in tourism and about terrorism as a threat for European tourism. If a terrorist attack occurs in a country, then it might make people think twice about visiting that place, and they may decide to change location. Risk is defined as uncertain event management in order to success. Risk is characteristic of all methods and means by which risk is managed to achieve the objectives described in the technical, social, human and political event analysed, having as basis the uncertainty major risk factors. Tourism is travel for pleasure or business; also the theory and practice of touring, the business of attracting, accommodating, and entertaining tourists, and the business of operating tours. Tourism may be international, or within the traveller's country.
\end{abstract}

Keywords: risk in tourism; European tourism; tourism; terrorism risk; terrorism threat.

JEL Classification: $Z_{30}, Z_{32}$

\section{Introduction}

As the world becomes a more dangerous place, there is an ever-greater need to identify risk and manage the risk. People throughout the tourism, traveller and visitor industries have begun to ask themselves questions such as: How much risk is acceptable risk? Can I afford insurance to cover the costs of the risk? What are the risks upon which I need to concentrate? [Tourism and more, 2002]

Risk management then in the travel and tourism industry is an on-going process that touches every aspect of the business, from the type of accounting practices used to the public's satisfaction with your company, from managing costs to dealing with issues of fraud. Risk is a part of every aspect of the travel and visitor industry and cannot be avoided. To fail to recognize risk is perhaps the greatest risk of all. [Tourism and more, 2002] 


\section{Issue $3 / 2017$}

A business performance means an investment in a project performance with predictable and planned activities. "It is envisaged that a successful organizational structure carries an activity projects, the latter being the only existing solution in the competitive economic world system with activities having a high degree of unpredictability. In this case, the investment must be made if predictable partners have activities on a predictable market, assessing and minimizing risk." [Opran, 2004].

The risk is not to be understood as a destructive element. The risk can lead to great opportunities for those who know how to use it. The goal is to know the risk and use it for our success. The solution is not complete avoidance of risk that is otherwise impossible, but avoid risks that cannot be understood, controlled and monitored and use the remaining risks in order to success. The existence of risk has led to the development of structures dealing with risk management. Human progress would not have been possible if the risk could have been avoided. [Opran, 2004]

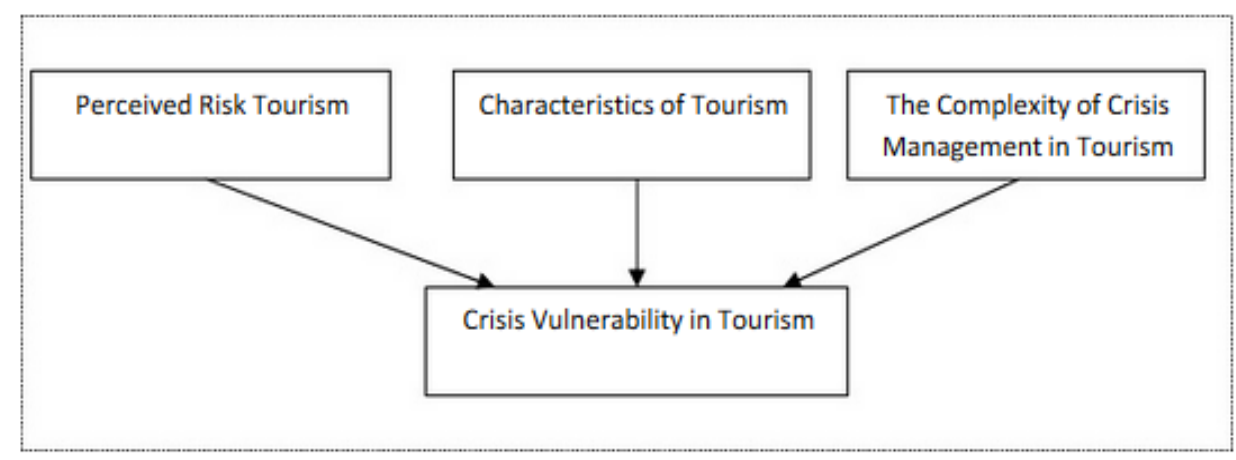

Figure nr. 1. Factors influencing crisis vulnerability in the tourism industry

Source: "Factors influencing crisis tourism vulnerability", "Campiranon Kom", accessed August 11, 2017, http://www.academia.edu/1455659/FACTORS_INFLUENCING_

$$
\text { TOURISM_CRISIS_VULNERABILITY }
$$

\section{Literature Review}

My research paper entitled: The Risk in tourism - Terrorism, a Threat for European Tourism, is written after I've documented on the basis of the following published articles:

1. "The Effects of Terrorism on the Travel and Tourism Industry" written by David Mc. A Baker, published on International Journal of Religious Tourism and Pilgrimage. 


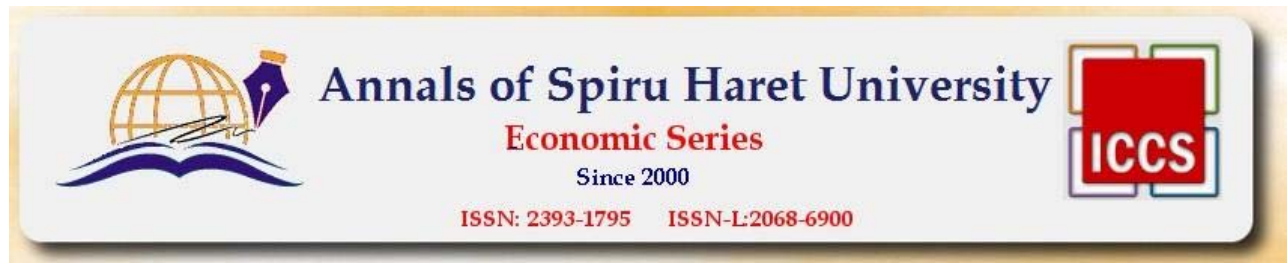

Issue $3 / 2017$

2. "Influence of Terrorism Risk on Foreign Tourism Decisions" written by Sevil F. Sönmez, published on Annals of Tourism Research.

3. "Efficacy of Internal Control and Controlling Business Risks" written by Luminita Ionescu, published on Annals of Spiru Haret University. Economic Series.

4. "The Impact of Terrorism on Tourism Demand" written by Jorge E. Araña and Carmelo J. León, published on Annals of Tourism Research.

5. "Terrorism and Domestic Tourist Risk Perceptions" written by David Adeloye and Lorraine Brown, published on Journal of Tourism and Cultural Change.

6. "Terrorism and Tourism: The Case of Turkey" written by Mehmet E. Yaya, published on Defence and Peace Economics Journal.

7. "Tourism's Vulnerability and Resilience to Terrorism" written by Anyu Liu and Stephen Pratt, published on Tourism Management Journal.

The Theoretical and Practical Value of the Current Study in the Tourism Risk

The research direction is to conduct a set of studies examining the relationship between tourism and security on a destination-specific basis. The aim of this direction is to further deepen the understanding of causes and effects in tourism and security relations. This can be achieved through an inductive research approach that moves from specific observations and measures, to detecting patterns and regularities, formulating empirical generalizations. [Pizam \& Mansfeld, 2006]

Concept definitions [Pizam \& Mansfeld, 2006]:

- Theory - an attempt to explain and predict a particular phenomenon.

- Proposition - a statement about one or more concepts or variables. Subtypes of propositions include hypotheses, empirical generalizations, axioms, postulates, and theorems.

- Hypothesis - proposition that is stated in a testable form and predicts a particular relationship between two (or more) variables.

- Empirical generalization - a statement of relationship that is constructed by first observing the existence of a relationship (in one or a few instances) and then generalizing to say that the observed relationship holds in all or most cases.

- Security incidents - an act of violence or threat of violence, such as crimes, terrorism, wars, and civil or political unrest committed at a tourist destination against tourists or local residents.

- Travel advisory - a statement issued by a government in a generating market intended to advise its citizens about possible risks involved in traveling to security affected destinations. 
Issue $3 / 2017$

- Destination-specific marketing strategy - a tactic employed by a local destination to disassociate itself from a larger tourist destination that has an undesirable security image.

Questions about research [Pizam \& Mansfeld, 2006]:

- Why do we need a theory on tourism security?

- Discuss the means by which it is possible to increase the prosecution rate of offenders who victimized tourists.

- What are the differences between the impacts of terrorism and the impacts of crime on affected tourist destinations?

- What is the typical reaction of destinations that suffer from a tourism security crisis?

- Which has a greater impact on tourism demand, frequency of security incidents or severity of security incidents?

- Discuss the methods employed by tourism enterprises to survive during serious tourism crises.

- What, if any, impacts do governments in the generating markets have on recovery from security crises?

The research objectives [Pizam \& Mansfeld, 2006]:

- To understand the process of theory building in the field of tourism security.

- To understand the importance of theory building as part of developing appropriate strategies to control the negative impacts security incidents have on the tourism system.

- To become acquainted with the fundamentals of tourism security theory.

- To become familiar with the nature of security incidents.

- To understand the array of impact security incidents have on tourists, the tourism industry, and the host community.

- To become aware of future research directions needed in order to refine or redefine tourism security theory.

Impact on the tourism industry [Pizam \& Mansfeld, 2006]:

In the case of leisure tourists on organized trips, the tourists' travel behaviour is facilitated by two stakeholders in the tourism system - tour operators in the generating markets and tour operators in the receiving destination. Both share a common objective of mitigating the almost inevitable damage resulting from a change in the security climate of a given destination. Since these stakeholders do not normally coordinate their reactions to security-oriented crises, each has to 98 


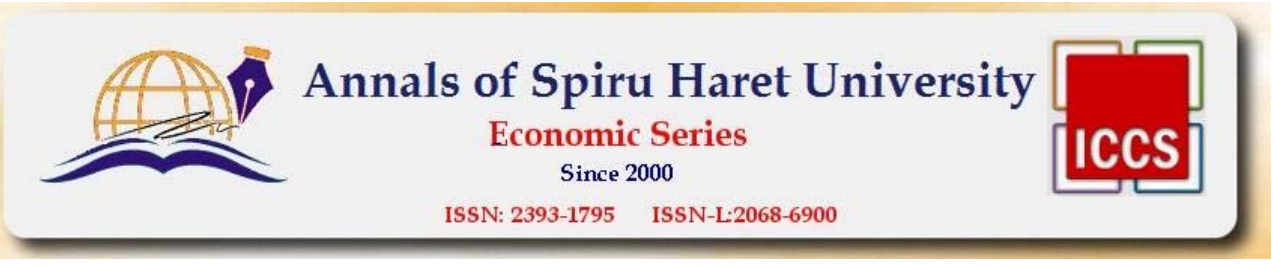

Issue $3 / 2017$

perform an individual assessment of the other side's actions taken to mitigate the damage. [Pizam \& Mansfeld, 2006]

The most common variables used to characterize the behaviour of the tourism industry in the wake of evolving security situations are [Pizam \& Mansfeld, 2006]:

- evacuation of tourists by tour operators;

- local investors' behaviour;

- transnationals' investing behaviour;

- human resource restructuring behaviour;

- inclusion/exclusion of destination in tour operators' brochures;

- cost of doing or ceasing doing business;

- cash flow assessment;

- profitability;

- projection of destination image by tour operators and travel agents; and

- extent of economic interest in tourism business at the destination.

Image and perception management [Pizam \& Mansfeld, 2006]:

When security incidents take place and the security situation in tourist destinations deteriorates, the result does not always lead to a long-term detrimental effect on the local tourism industry. However, when the situation involves global media coverage, the information it conveys creates a strong negative image among potential tourists. If this negative image is translated by would-be travellers into unacceptable risk levels, potential tourists would most likely cancel their bookings or choose to book alternative and more secure destinations. It is, therefore, in the interest of the tourism industry and host governments to try to balance the negative images by conveying their own more accurate, less biased, and marketing-oriented messages. However, in order to choose the right strategy in pursuit of a better perception management, affected destinations have to detect and analyse the perceived images and their interpretation by their potential markets. [Pizam \& Mansfeld, 2006]

The following variables are to be used in order to unveil the characteristics, image, and risk perception of security affected destinations [Pizam \& Mansfeld, 2006]:

- nature of perceived destination image following security incidents;

- levels of perceived risk;

- effect of mass media on destination image;

- effect of travel trade on destination image;

- effect of friends and relatives on destination image;

- effect of risk-taking tendency on destination image; and 

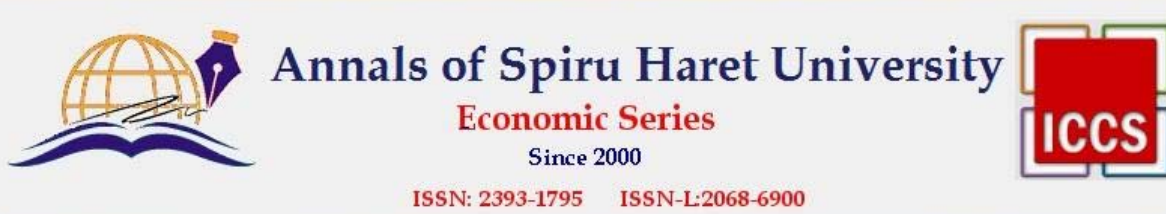

Issue $3 / 2017$

- effect of risk takers' experience on destination image.

Risk and crisis management (prevention/reduction/mitigation) techniques [Pizam \& Mansfeld, 2006]:

Past experience shows that forward-thinking destinations that were concerned about being affected by security incidents dealt with the situation in one or both of the following ways, either before an incident took place, or when an incident occurred and caused some sort of tourism crisis. In the first case, destinations prepared themselves by developing contingency plans as part of a proactive risk management policy. In the second case, when an incident occurred, these destinations pulled their crisis-management plans out of the drawer and implemented them. Obviously, the better a destination was prepared the more effective was its response to the security crisis. However, for both cases, the effectiveness of its prevention, reduction, and/or mitigation plans was a function of the cooperation between all tourism stakeholders in the affected destinations and between these stakeholders and those in the generating markets. [Pizam \& Mansfeld, 2006]

Common variables evaluating the extent of operational cooperation and success of crisis management plans are [Pizam \& Mansfeld, 2006]:

- availability of risk related information to tourists and potential tourists;

- availability of integrated contingency marketing plans for each crisis stage;

- availability of media and image-management plans;

- availability of attractive incentives for domestic tourists;

- level of labour cost reduction in private enterprises;

- level of dissemination of positive communication;

- development, operation, and updating of travel advisories among generating markets and host destinations;

- presence of law enforcement or the military in tourist zones;

- level of technologically based means of protection in and around tourism installations;

- availability of dedicated tourist police units;

- level of dedicated tourism policing;

- level of visibility of security measures;

- availability of rewards for information leading to arrests of offenders;

- facilitation of tourist victims' testimony in criminal cases;

- training of tourism employees in security matters;

- public-private cooperation in security provisions;

- availability of tourism and security education programs; 


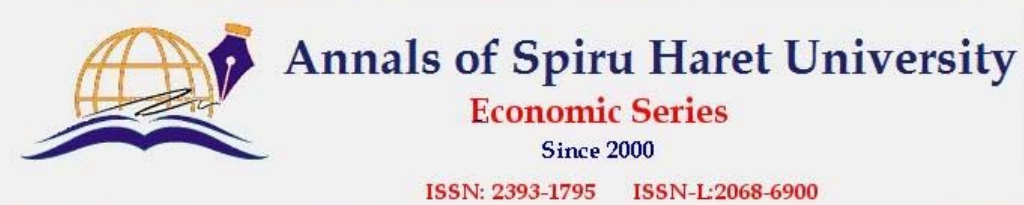

Issue $3 / 2017$

- adoption of cpted (crime prevention through environmental design) principles in the design of tourism physical plants;

- designating crime against tourists a major criminal offense;

- maintaining a database of crimes against tourists;

- educating local citizens;

- creating and maintaining safe roads; and

- partnership between the leaders of the local community and governments.

Recovery methods:

Past experience has shown that those destinations that conducted wellcoordinated efforts to regain tourists' trust when the crisis was over managed to increase tourist demand and recovered in a relatively short time. Recovery efforts involved various actions taken by different tourism stakeholders. But in all cases these actions were successful only when they were backed by sufficient financial resources. [Pizam \& Mansfeld, 2006]

Measuring the effectiveness of recovery methods uses the following most common variables [Pizam \& Mansfeld, 2006]:

- the effect of price reduction strategies;

- availability of funds for marketing recovery plans;

- ability to develop new market segments;

- availability of new and innovative promotional campaigns;

- availability of destination-specific marketing strategies;

- effectiveness of marketing campaigns by the private sector;

- availability of comprehensive marketing campaigns by Destination Management;

- organizations (DMOs), non-governmental organizations (NGOs), and governments;

- scheduling of special events;

- availability of incentives to tourists;

- availability of financial assistance from governmental agencies;

- level of local community involvement in recovery oriented efforts;

- level of positive public relations campaigns to improve public opinion among the media, tourists, and locals;

- level of disseminating positive information to existing and potential tourists. 


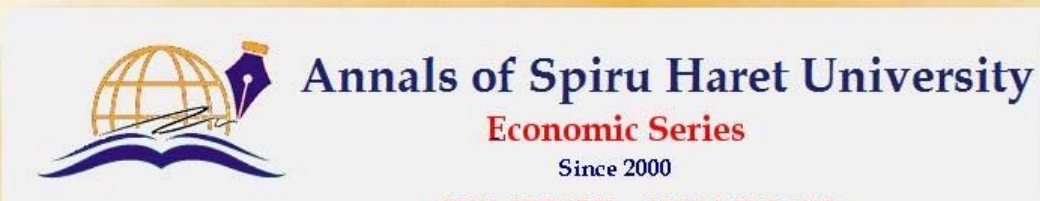

ISSN: 2393-1795 ISSN-L:2068-6900

Issue $3 / 2017$

\section{The Differential Effects of the Perceived Terrorist Threats in Different Markets}

Terrorism, a phenomenon that has existed in various forms for over 400 years, is a highly complex topic. It is so complex that there is a whole scholarly literature dedicated to understanding it and its impact on both tourism and world economies. [Tourism and more, 2016b]

Furthermore, despite the public's desire for total travel and tourism security and safety, no one can guarantee a pain-free and totally secure travel experience. Even the best experts cannot predict every act of terror and no one can control a free media. Especially in an age where terrorism risk is not only part of the travel and tourism experience, risk it is also a part of life. [Tourism and more, 2016b]

It is strongly recommended that tourism experts consult on a continuous basis with travel security experts before implementing any policy decisions. To do less is to place the travelling public in undue risk. [Tourism and more, 2016b]

The tourism industry, if it is to survive in an ever changing and more challenging world will need to consider various paradigm shifts. Among these shifts are the following [Tourism and more, 2016b]:

- The tourism industry needs to come to the sad but true realization that it is not merely collateral damage within the world of terrorism, but rather that tourism is one of terrorism's principal targets. Tourism stands for everything that threatens terrorists. Tourism is about open societies in which we judge each person on his or her merits. Terrorism is just a modern form of Nazism, where people are judged not by who they are but to which social, national, or religious group they belong.

- The tourism industry will have to find a way to creatively protect its customers, without creating so many travel difficulties that travel becomes unbearable. Currently, tourism safety and security are more about "security-theatre" than about real security. Airport security is often reactive and haphazard at best. All too often those working in it are often poorly trained and paid resulting in personnel whose actions are all too often unprofessional.

- Tourism education will need to include courses on tourism safety and security. These courses are rarely taught. Once again, universities are not keeping pace with a changing world. This lack of cutting edge thought combined with political correctness means that future leaders in tourism will not be prepared to deal with a changing world.

- The tourism industry needs to become much more knowledgeable about terrorism and violence. The media and politicians from all sides of the spectrum continue to use misleading words such as "lone wolf" or "lone wolf attacks". These 


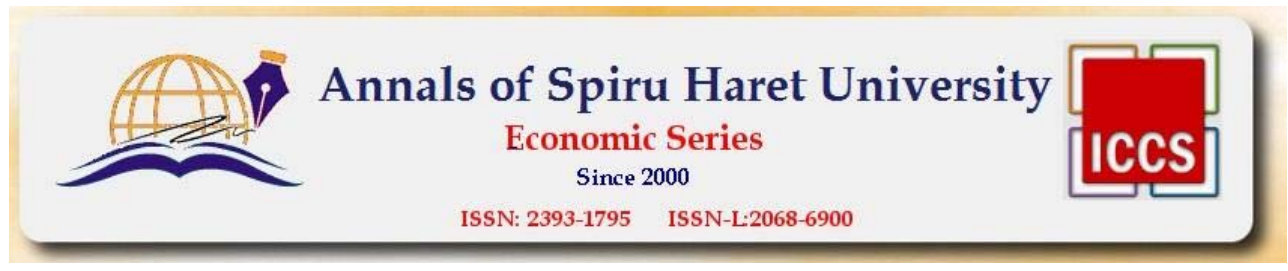

Issue $3 / 2017$

terms are not only misleading, but also often dangerous and misleading. The use of a false narrative creates either a sense of ennui, despair, or "miss-actions". Tourism officials need to get beyond political correctness and, as the Egyptian government has done, actually identify culprits and then begin to face ideological warfare.

- Tourism officials must learn to coordinate their marketing strategies with their security experts. Most tourism centres have a great deal of demographic information. Yet often various tourism departments fail to share information with each other. Just as security professionals must realize that their actions impact the way that tourism is marketed and thrives, so too must marketing experts come to realize that they must coordinate their campaigns with their tourism security experts. To make matters worse, too many tourism entities lack a tourism safety and security manager or department.

- Tourism security experts must realize that no two tourism entities are the same and that tourism needs individualized security tailored to a particular locale rather than a one-size-fits-all approach. This realization means that security experts need to take into account such variables as: language spoken by visitors at specific locales, visitors' age ranges, and visitors' special physical needs. Because the list of variables is almost infinite, the best forms of risk management need to be employed so as to gain the most protection from available resources.

- Tourism marketers will have to come to the realization that these problems cannot be covered over. No matter how much money the tourism industry spends are feel-good marketing, it cannot market away terrorists' threats to the industry. Currently, marketers dominate the tourism industry. Marketers tend to find lots of money for advertising but never seem to have the funds to promote security. The tourism industry says it is interested in protecting its clients, but rarely are words turned into action. Instead, a great deal of caring is expressed during a crisis and then once the crisis passes the industry returns to business as usual.

- Tourism officials need to know when to discourage tourism. Although it is almost impossible to predict a specific terrorist attack, such as that which occurred in Nice, France, other manifestations are predictable. The absolute best protection is not to be at that locale. This statement does not mean that we should not travel. As noted above, merely living is a form of risk-taking. It does mean that certain geographic sections of the world have specific risks and that tourism officials must be aware of those risks, explain the risks honestly, take measure to mitigate the risks and have a recovery plan in place should the risk occur.

- The tourism industry needs to have real recovery plans in place. This means that medical plans need to be coordinated prior to a terrorist attack and not as an after-thought. For example, if your community has a manor stadium or other areas 


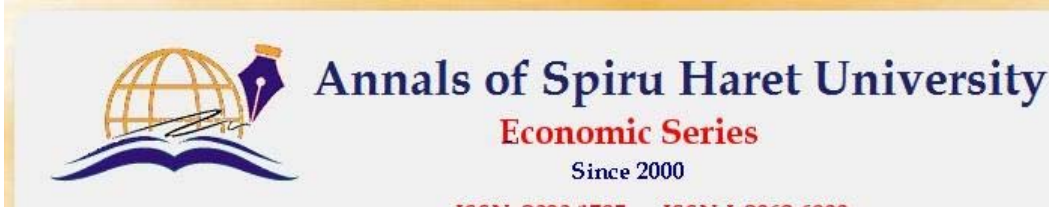

ISSN: 2393-1795 ISSN-L:2068-6900

Issue 3/2017

with large crowds, be sure that there is both an evacuation plan and a triage plan put in place. Practice these plans and know what their weaknesses are. Make sure that there is a communication plan in place and a way to get needed cash or lines of additional credit for visiting victims.

These are only a few of the generalities that tourism leaders will need to consider now and into the future. Terrorism and acts of criminality and violence cannot be solved with nothing more than innovative marketing. These social cancers must be faced, diagnosed and defeated. With a modicum of certainty we can predict that locations such as Europe will see higher levels of terrorism. These social sores can ignite in a form of societal spontaneous combustion. [Tourism and more, 2016b]

These are real problems that deserve the attention of all who care about the world's largest peacetime industry. If the tourism industry chooses to face these issues head-on then it shall become a major force for peace in the world, but if it chooses a form of marketing-ostracism than it may expect further bloodshed and negative headlines. The choice is up to us. [Tourism and more, 2016b]

\section{Avoiding Becoming a Victim in Tourism or Travels}

Travel is no doubt a wonderful experience. It broadens our horizon, permits us to understand new societies, allows us to see things about which we have only dreamt, and gives us the opportunity to see ourselves in entirely new ways and often as others see us. [Tourism and more, 2016c]

Unfortunately, when some people travel they may also do things that are both foolish and harmful. Some of the things that, when travelling, we want to avoid. For those in the travel industry, it is essential to understand these sociological phenomena so that they can be taken into account and planned for. These principles are important because these same sociological phenomena often occur to both business and leisure travellers, to men and to women, to the teenager and to the senior citizen. When these problems occur tourists and visitors rarely blame themselves, but rather tend to blame the locale resulting in negative word-of-mouth advertising. [Tourism and more, 2016c]

A key point for all tourism professionals is the realization that travellers have choices. In the case of the leisure market this assumption almost always holds true. In the business word, business travellers are finding ways to replace some business meetings by other forms of virtual communications. [Tourism and more, 2016c]

Tourism industries that believe that they are essential can easily suffer calamities if they are not careful with their customer service and their creation of safe and secure locations. In the case of leisure travellers, often these travellers 


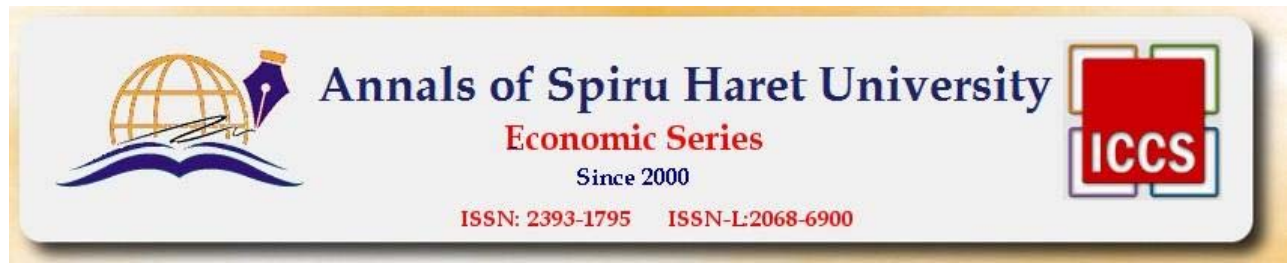

Issue $3 / 2017$

assume that the place to which they are travelling is safe and as such often lower their level of caution. [Tourism and more, 2016c]

The following principles often reflect some of the common mistakes that we make when it comes to travel and to those who are our customers. [Tourism and more, 2016c]

Outline of some of the common mistakes that we all make whenever we travel and phenomena about which we want to be mindful. Part of the challenge of being a tourism professional is advising visitors about security and safety while at the same time not scaring them. This balanced approach is one of the reasons that tourism units are so essential. These travel security professionals, be they public or private security officers, are an essential part of tourism's front line [Tourism and more, 2016c]:

- Travel is stressful. No matter what we in the tourism industry want to believe, travel is stressful and stress places us in danger. Prepare your guests for the stress of travel by having reminding them to have alternative plans, to take needed telephone numbers, and making sure that they carry food and water in case of delays. Criminals know that when we are under stress we tend not to think, leave things (such as wallets and passports) exposed and tend to speak louder. Remember when the traveller is under stress; the criminal is not. That means, take the time to remind customers to put wallets away, not to expose credit cards, and when using a public phones or ATM machines to block access so that someone cannot photograph the person's code.

- When we travel we often seem to leave our common sense behind. Part of the reason for this phenomenon may be that we assume that to where we are going is safe, or that nothing will happen to use when we are travelling. Nothing could be further from the truth. Crime exists everywhere and police departments around the world are understaffed and over-stretched. To add to this, recent historical trends have shown that terrorism is a growing problem.

Terrorism a Threat for European Tourism

The terrorist attacks caused instability in some European countries; such problems have put those who want to spend their holiday in a destination until recently regarded as safe. Many European countries have gone from being among the most popular holiday destinations to being countries with "threat of terrorism". [Mihalache, 2016]

Security experts around the world have proposed a rethinking of security measures at airports after the attack occurred in Istanbul. And British Foreign 


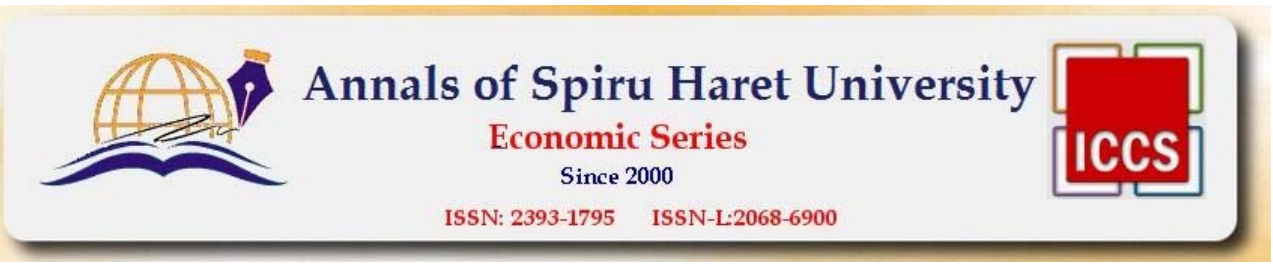

\section{Issue $3 / 2017$}

Ministry has updated information on the risks tourists going on holiday in Europe may face. [Digi24, 2016]

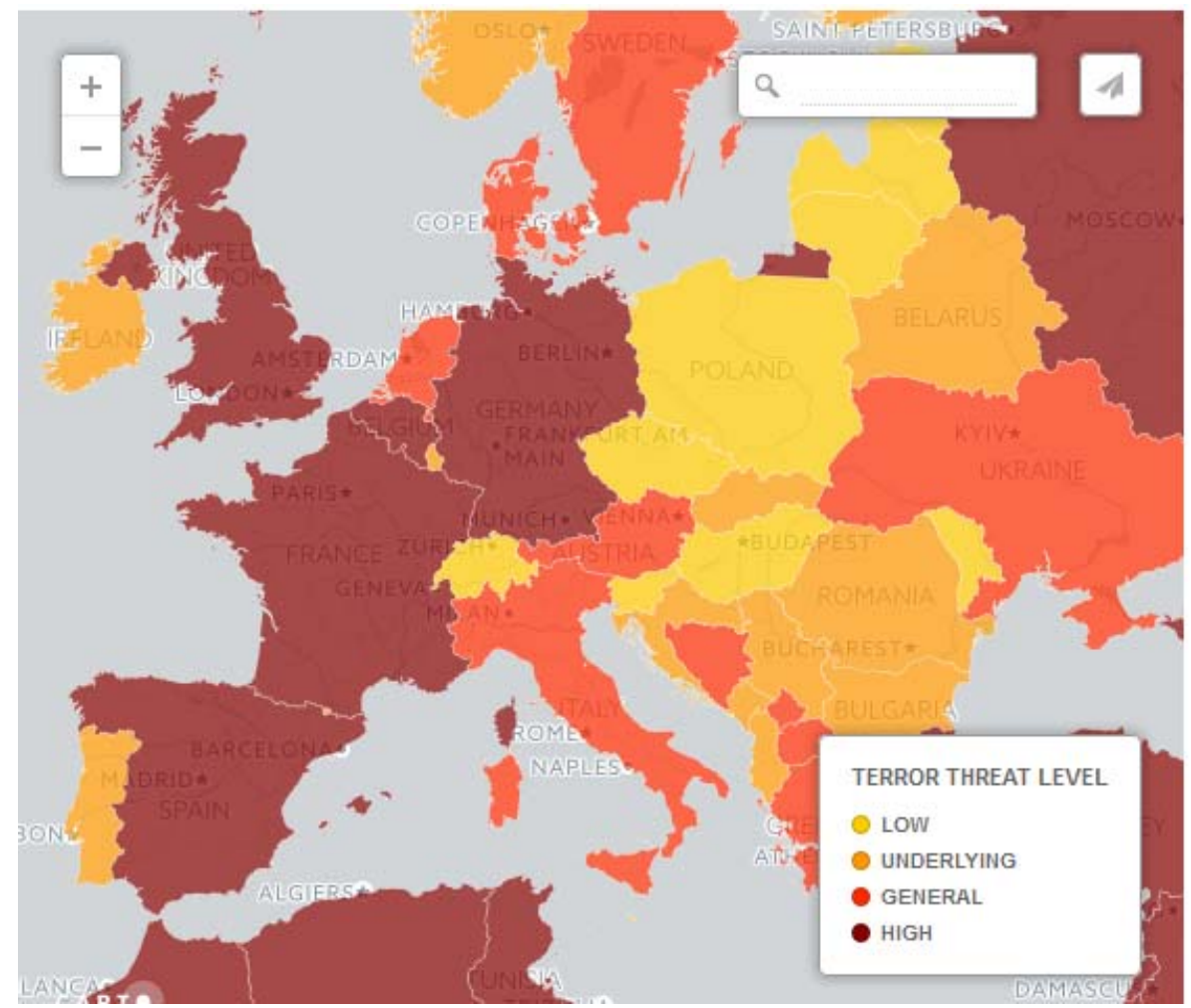

Figure nr. 2. Terror Threat Level

Source: The Telegraph (2017),"Is Turkey safe for tourists and can I cancel my holiday?" accessed August 11, 2017, http://www.telegraph.co.uk/travel/advice/is-turkey-safe-fortourists/

The prevailing paradigm argued that terrorists were most likely to strike locations that were high on the following scales [Tourism and more, 2016a]:

- They were centres where a great deal of economic damage would occur.

- They were centres could generate mass casualties.

- They were places that had some form of iconic significance.

- They were places that were most likely to be covered by the media. 


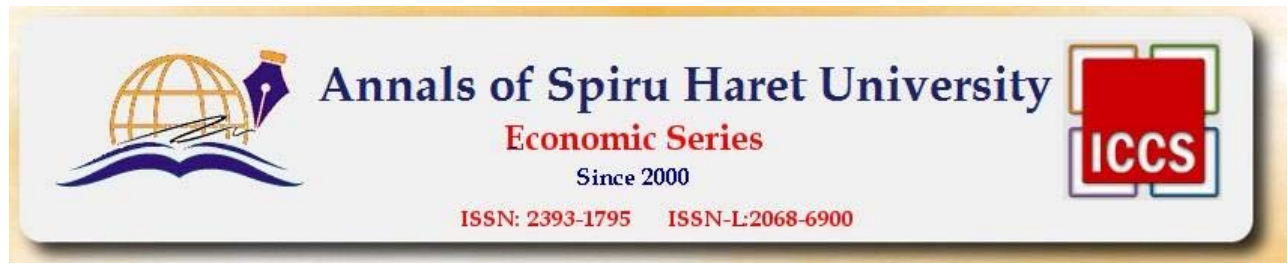

Issue $3 / 2017$

Among the new realities that tourism professionals need to consider, there are [Tourism and more, 2016a]:

- Tourism is often a magnet for terrorists. Tourism values are the antithesis of terrorists' values. Furthermore, the tourism industry is too large and diverse that it provides multiple targets for those seeking to create economic chaos.

- The fear factor combined with terrorism's unpredictability may well impact world tourism and the world's economy. Terrorists do not need to carry out a successful attack, they merely need to create a sense of fear. Although business people will continue to travel, the leisure passenger may well pull back. People may well become afraid not only to travel to major tourism centres such as London and Paris but also to less famous or popular destinations.

- Attacks against non-tourist specific locations still act as passive attacks on tourism. Terrorism is based on fear and the greater the public fears being away from home, the more precarious is the tourism industry's situation. Terrorists do not need to target a tourism industry actively to do it damage, a passive attack or a failed, but publicized attack is still a success from the terrorists' perspective.

- Due to high levels of publicity, a terrorist attack in any one location raises traveller anxiety levels around the world. Due to the fact that terrorism is now a worldwide phenomenon, an attack in any one location means that visitors are not only increasingly fearful, but that these attacks may cause people to cease to travel or to travel less, thus impacting the entire industry.

- Think of unlikely scenarios. Terrorists do not only need to use deadly force, they can create a tourism crisis by means of cyber-attacks, social media or simply creating rumours that create fear within the travelling public. In today's media interconnected world news spreads at extremely rapid speeds and can cause fear and cancellations not only at a particular locale, but across the globe.

Countries where the risk of a terrorist attack is considered high-risk are UK, Belgium, Germany, Turkey and Russia. Follow the Netherlands, Denmark, Sweden, Italy, Austria, Bosnia Herzegovina, Montenegro, Greece, Ukraine and Cyprus. [Digi24, 2016]

Spain is one such example, until recently one of the favourite destinations of tourists from around the world, and now, the state from the Iberian Peninsula is on the list of countries with a high level of terrorist activity. The Spanish authorities also urge tourists who want to visit the Iberian Peninsula to be vigilant and follow the instructions of local authorities in case they want to choose this country as the next tourist destination. [Mihalache, 2016]

France is also on the list of countries with an imminent danger to tourists who choose to travel here, especially after more than a year ago Paris and other cities 


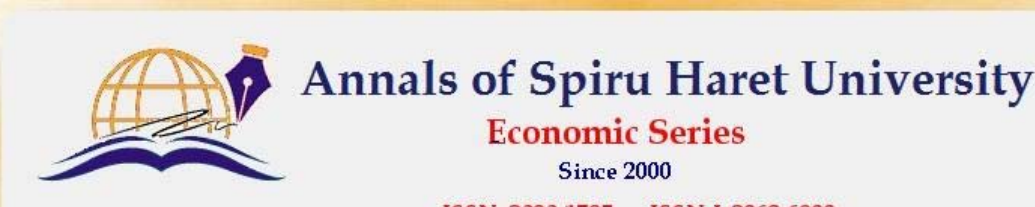

ISSN: 2393-1795 ISSN-L:2068-6900

Issue 3/2017

have been targeted by terrorists. Government intervention in Paris following the attacks claimed by Islamic terrorists has increased over France and the French authorities advised citizens and tourists to be vigilant for any suspect that would appear in public places. [Mihalache, 2016]

Tourism in another top city - Paris - has been hard hit in the wake of terror attacks. [Petroff, 2017]

Paris has been forced to ramp up security measures and erect barriers around the Eiffel Tower to guard against terror threats. [Petroff, 2017]

France as a whole experienced a 7.3\% drop in tourism spending in 2016, according to the World Travel \& Tourism Council. The Louvre museum has seen attendance fall by $21 \%$ over the past two years. [Petroff, 2017]

London tourism at risk after terror attack [Petroff, 2017]:

- The incident occurred in a key destination for tourists in central London, where visitors often gather to take pictures of Big Ben and the Houses of Parliament. Some of the injured victims were visiting from countries including France, Australia and China.

- The attack could have a major impact on London's booming tourism industry - especially in the busy summer months to come. The capital city welcomes up to 20 million visitors per year, making it among the top three most visited destinations in the world.

- Some travellers may now choose to wait before booking flights to London. Other tourists may cancel their trips or avoid the city altogether.

- London tourist spending has grown rapidly over the past year, increasing by more than $7 \%$ to nearly $\$ 20$ billion in 2016 .

Tourism directly supports roughly 500,000 jobs in the capital, according to U.K. Tourism Alliance.

- About half of all U.K. travellers visit London during their trips.

- London officials will be hoping to avoid a hit to tourism similar to the one suffered by Paris in the wake of a series of high-profile terrorist attacks.

According to statistics, the British prefer to go on holiday in Greece, Spain or Portugal. All Greece is most popular with tourists from Germany and the French choose as favourites, Portugal, Spain and Italy. [Digi24, 2016]

Following recent attacks, Germany is also in the top of the countries that people should think twice before planning a holiday. [Mihalache, 2016]

Countries where the risk of a terrorist attack is considered unlikely are Bulgaria, Romania, Portugal, Ireland, and other countries in the Balkans and northern and central Europe. The safest destinations are Moldova, Switzerland, Slovenia, Czech Republic, Hungary, Poland. [Digi24, 2016] 


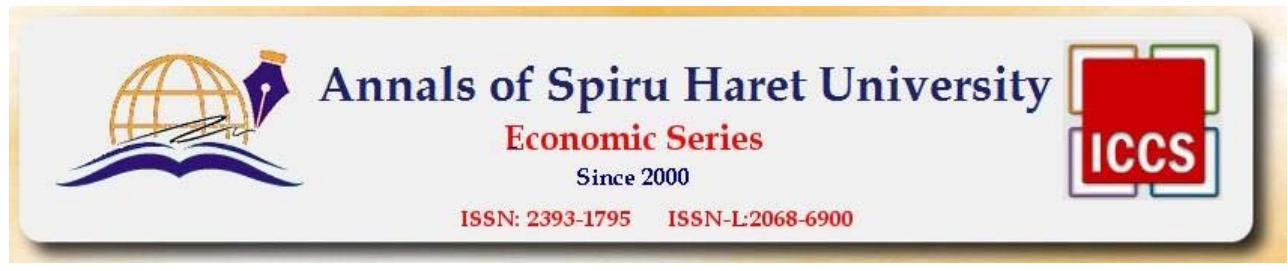

Issue $3 / 2017$

Until now, because of the terrorist attacks, tourism in Turkey has suffered the most. Yet people living in Istanbul see things differently. In Turkey, the occupancy rate is about $50 \%$ and many reservations are cancelled.

Many tourists would not take this risk especially for families who have small children. [Digi24, 2016]

In this context, where tourists can travel without worrying? A lower level of terrorist threat is in Greece, one of the most popular summer destinations in Europe. However, authorities in Athens advise tourists to be careful near the institutions and shopping centres frequented by tourists, where were the latest attacks in 2013 and 2014. [Mihalache, 2016]

\section{Strategies for Combating Terrorism in Europe}

Terrorism is not a new phenomenon in Europe. It poses a threat to our security, to the values of our democratic societies and to the rights and freedoms of European citizens. [European Council, 2017]

Since these threats do not recognize borders, they must be confronted at both national and international level. [European Council, 2017]

Prevent: One of the European Union priorities in the field of counter-terrorism is to identify and tackle the factors which contribute to radicalization and the processes by which individuals are recruited to commit acts of terror. To this end, the Council adopted a European Union strategy for combating radicalization and recruitment to terrorism. [European Council, 2017]

Protect: The second priority of the European Union counter-terrorism strategy is the protection of citizens and infrastructure and the reduction of vulnerability to attack. This includes the protection of external borders, the improvement of transport security, the protection of strategic targets and the reduction of the vulnerability of critical infrastructure. [European Council, 2017]

Pursue: The European Union is working to hinder terrorists' capacity to plan and organize, and to bring these terrorists to justice. To achieve these goals, the EU has focused on strengthening national capabilities, improving practical cooperation and information exchange between police and judicial authorities (in particular through Europol), tackling terrorist financing and depriving terrorists of the means by which they mount attacks and communicate. [European Council, 2017]

Respond: The fourth objective of the EU counter-terrorism strategy is to prepare, in the spirit of solidarity, to manage and minimize the consequences of a terrorist attack. This is done by improving capabilities to deal with the aftermath, the coordination of the response, and the needs of victims. Priorities in this area include 


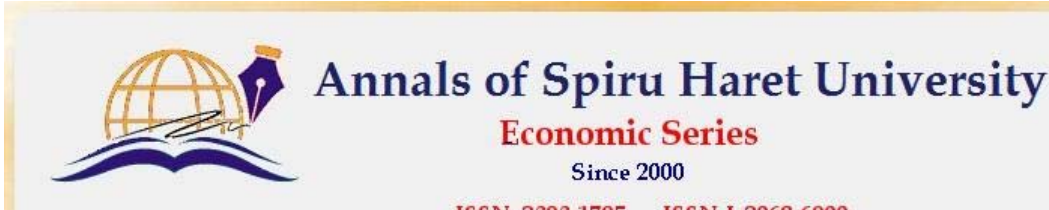

ISSN: 2393-1795 ISSN-L:2068-6900

Issue 3/2017

the development of EU crisis co-ordination arrangements, the revision of the civil protection mechanism, the development of risk assessment or the sharing of best practices on assistance to victims of terrorism. [European Council, 2017]

Engagement with international partners: In the relations between the European Union and third countries, the counter-terrorism agenda is present in many ways, through high level political dialogues, the adoption of cooperation clauses and agreements, or specific assistance and capacity building projects with strategic countries. The EU cooperates on counter-terrorism with countries in the Western Balkans, North Africa, the Middle East, the Horn of Africa and North America, as well as in Asia. [European Council, 2017]

Cooperation with the US is a fundamental component of the EU strategy. In recent years, cooperation agreements have been reached in areas such as the financing of terrorism, transport and borders, mutual legal assistance or extradition. US authorities are working more and more closely with Europol. [European Council, 2017]

Another important part of the external dimension of the fight against terrorism involves working closely with other international and regional organizations to build international consensus and promote international standards for fighting terrorism. The European Union works with international organizations including the UN and the Global Counter Terrorism Forum, and regional organizations such as the Council of Europe, the OSCE, the League of Arab States or the Organization for Islamic Cooperation. [European Council, 2017]

As part of its cooperation with the UN, and following a number of UN Security Council resolutions, the EU has adopted certain restrictive measures against persons or entities associated with the Al-Qaeda network. [European Council, 2017]

Here are a few things that tourism professionals can do to be prepared [Tourism and more, 2016a]:

- Tourism professionals need to obtain their news from various sources. Terrorism breeds confusion especially in smaller locales. It is essential that the tourism professional have a wide gamut of information and that he or she does not allow personal political feelings to mix with hard news and facts. Terrorists want the tourism industry professionals to become politicized, and thus it is easier for them to destroy the tourism industry.

- Have a tourism-terrorism task force in place. This task force should include not only tourism savvy members of law enforcement, but also medical personnel, media specialists, hoteliers and restaurateurs, transportation specialists and professionals, and community political leadership. It is essential that there be collegial trust 110 


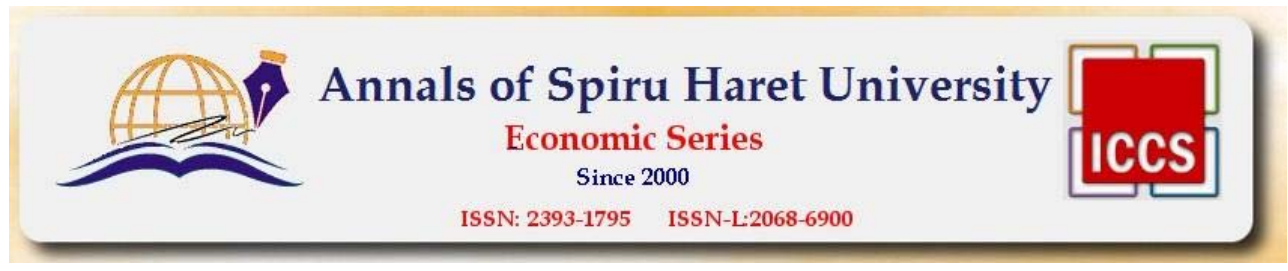

Issue $3 / 2017$

between the team members. The better your ability to work with each other the better a crisis can be handled or adverted.

\section{Empirical Generalizations about Risk in Tourism}

For the purpose of constructing a tourism security theory, empirical generalizations were developed because by now researchers have had the opportunity to observe numerous tourism security crises throughout the world and have examined their impacts on the tourists, the destinations and the tourism industry. [Pizam \& Mansfeld, 2006]

The next stage in the development of tourism security theory was the formation of these empirical generalizations. [Pizam \& Mansfeld, 2006]

Impact on the tourism industry [Pizam \& Mansfeld, 2006]:

- Peace, safety, and security are the primary conditions for successful tourism development.

- Tour operators are severely affected by unexpected security incidents. This is due to their large investments in purchasing tourist products that might perish following a security incident. Moreover, the cost of finding alternative solutions for tourists who have already booked their trips to affected destinations is high and might even lead to business failure.

- In times of security crises, government-regulated tour operators are the first to react and will either evacuate their guests, exclude the affected destination from their travel brochures, stop operation in destinations already included in their products, or temporarily relocate their traveling clients.

- Security incidents at tourist destinations result in diminishing tourist arrivals. Consequently, affected destinations lose both professional employees and entrepreneurs, who are essential for the successful operation of the tourism industry.

- In destinations that have been affected by security incidents the quality of tourist installations and services may become degraded, since many employees are made redundant and funds for regular maintenance are not available. The long-term implication is a need to reinvest large sums of money on rehabilitation of the affected infrastructure and superstructures once the security situation is over.

- Many transnational tourism companies-mainly international hotel and restaurant chains-tend to cease their operation in security affected destinations, causing major damages to their marketing infrastructure by removing affected destinations from their global distribution networks.

- Following severe or frequent security incidents many tourism companies in affected destinations have to restructure their human resources, which means 


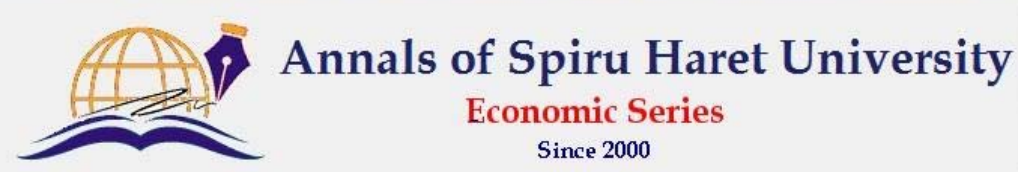

making many employees redundant and operating their services on a very tight budget. This has major bearing on the quality of service provided and on the level of satisfaction of those tourists who are willing to take the risk and visit these destinations.

Image and perception management [Pizam \& Mansfeld, 2006]:

- Only a small number of destinations practice image management following a security incident for the purpose of diminishing the negative image created by the media.

- When governments, and/or the tourism industry of the host destinations do not issue frequent and up-to-date security-related information during security crises, potential and existing tourists base their perceptions of risk on the images conveyed by external and often exaggerated media sources.

- Risk reduction strategies, such as dissemination of positive communication, influence the risk perception of not only potential tourists who are engaged in a destination-choice process, but also to those who:

o have booked but not already taken their trips;

0 are in the process of visiting the destination;

0 are returning from a recent trip.

Risk and crisis management (prevention/reduction/mitigation) techniques [Pizam \& Mansfeld, 2006]:

- Tourism security crises are for the most part unavoidable, since they are generated in many cases by exogenous factors that are beyond the control of the tourism industry or the tourist destination.

- Travel advisories issued by foreign governments are perceived by affected destinations as influential and, therefore, result in some actions being taken by the tourism industry and/or governmental tourism agencies.

- Improving tourist security by housing tourists in gated all-inclusive resorts has a negative effect on small tourism businesses, which feel shut out and reinforce the perceptions of inequality between tourists and local residents.

- Many tourism practitioners feel that too many visible security measures will cause visitors to wonder if they should be afraid and thus even speaking about these subjects could frighten customers.

- Tourist destinations that have created special police units aimed at preventing and reducing crimes against tourists have managed to reduce their tourist crime rates and/or have lower tourist crime rates than their counterparts. 


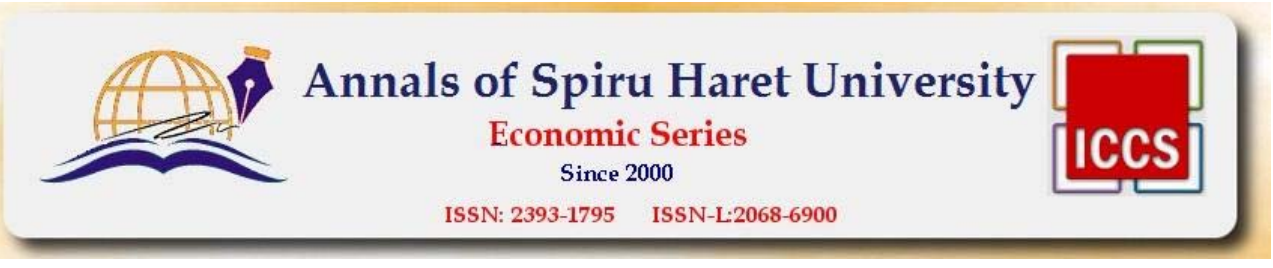

Issue $3 / 2017$

- Tourism police units that are effective in the reduction and/or prevention of crimes against tourists normally conduct the following activities:

- train their officers in tourism issues;

- are visible, accessible, and friendly to tourists;

- work closely with the community and tourism industry representatives;

- advise and train tourism industry employees in crime prevention techniques;

- assist the tourism industry by conducting background checks for employees;

- facilitate tourist victims' testimony in criminal cases;

- encourage tourism enterprises to adopt crime prevention/reduction practices;

- develop and implement tourist education programs aimed at reducing the risk of being victimized;

- increase the presence of uniformed officers in tourist zones.

- Tourist destinations that offer rewards for information leading to the arrest and conviction of those who commit serious crimes against tourists have better records of conviction, and in turn lead to lower rates of crimes against tourists.

- Crime prevention/reduction methods, such as security hardware and security policies that are used by tourism enterprises have varying levels of effectiveness.

- Destinations that collect and maintain tourism crime data at the property and destination levels are better able to evaluate the effectiveness of crime prevention/ reduction techniques than their counterparts.

- Destinations that have made crime against tourists a major criminal offense have lower crime rates committed against tourists than do their counterparts.

- Tourist destinations that established a partnership between law enforcement agencies, tourism enterprises, the community at large, and the tourists themselves have lower crime rates than do their counterparts.

- Tourist destinations that established a partnership between the leaders of the local community and the national and local governments have been more successful in the prevention/reduction of acts of riot and political unrest at tourist destinations than their counterparts.

Recovery methods [Pizam \& Mansfeld, 2006]:

- In the aftermath of a decline in tourist visitation that is caused by a security incident, most tourist enterprises will try to reduce their operational costs by lying off a proportion of their employees.

- Following terrorist incidents, the tourism industry in the affected destination will seek to compensate for declines in leisure travel by appealing to local, regional, and national governments to promote and encourage government-related business travel. 

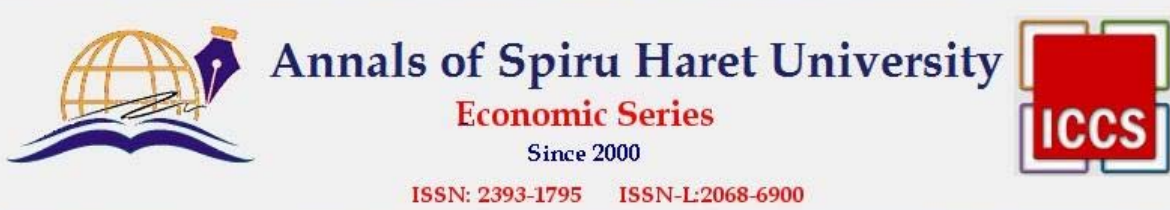

Issue $3 / 2017$

- In the aftermath of terrorist incidents, tourist enterprises seek to compensate for international tourists' declines by reducing their prices to appeal to domestic tourists.

To recover from a decline in tourist arrivals caused by security incidents, the public and/or private sectors of the affected destination will in most cases undertake:

- intensive marketing campaigns to convince the general public that things are back to normal; tourists.

- the scheduling of special events to attract local residents and out-of-town

To recover from the decline in tourist visitations caused by a security incident, the private sector at the affected destination will, in most cases, reduce prices and offer a variety of incentives to bring the tourists back to the destination.

Some marketing campaigns initiated after a terrorist attack aim to encourage area residents within a short drive of the affected destination to visit their region or hometown by appealing to their sense of local patriotism.

Destinations that are able to effectively recover from the aftermath of terrorist incidents use a combination of the following strategies:

- establish a mechanism for sharing information and coordination of publicity and PR activities aimed at creating positive public opinion among the media, local community, and customers;

- engage their local community in the effort of recovery;

- reassure and calm their existing and potential clients by providing them with current and updated information aimed at persuading them that the destination is open for business as usual;

- secure funding for the development and implementation of a recovery marketing plan.

Following one or a series of security incidents, to compensate for the resultant decline in tourist arrivals, tourism enterprises will employ one or a combination of the following strategies:

- reduce labour costs;

- decrease prices for their services and goods;

- initiate new promotional campaigns;

- develop new products:

- identify and develop new market segments;

- postpone major expenditures on maintenance and renovation;

- request financial assistance from governmental agencies. 

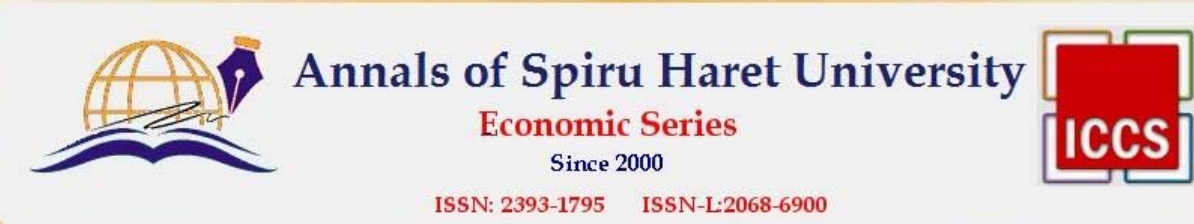

SSN: 2393-1795 ISSN-I-2068-6900

Issue $3 / 2017$

\section{Conclusion}

The overall actions in Europe on counter-terrorism are [European Union External Action, 2016]:

- Establishment and implementation of specific EU Counter-Terrorism regional and country strategies/Action Plans: Syria/Iraq CT/Foreign Fighters strategy, EU, Pakistan CT/security strategy, development and security strategy and EU Horn of Africa/Yemen Counter-Terrorism Action Plan.

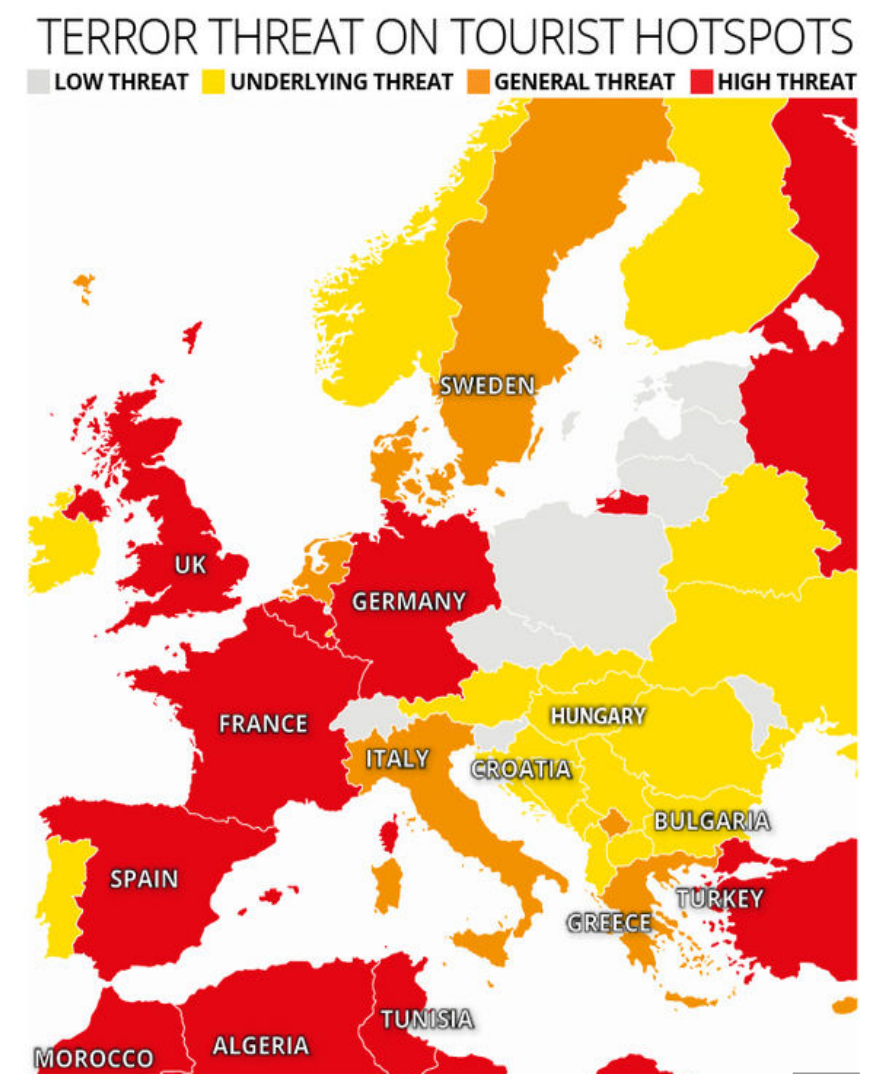

Figure nr. 3. Terror threat on tourist hotspots

Source: Express (2016), "How safe is your holiday? Mapped: Tourist hotspots with terror threat level now at high", accessed August 11, 2017,

http://www.express.co.uk/news/world/587227/Holiday-terror-threat-level-Spain-Tunisiaand-France-on-high-alert 

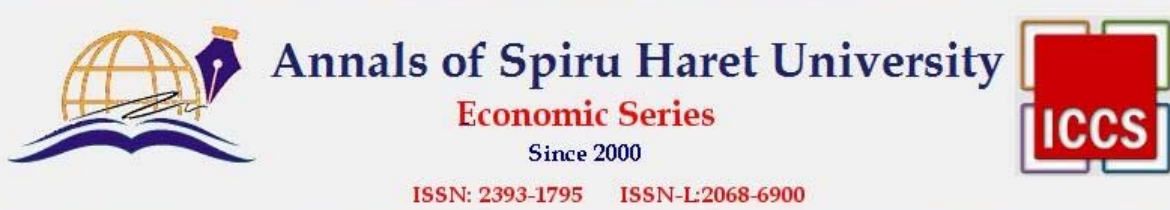

ISSN: 2393-1795 ISSN-I-2068-6900

Issue $3 / 2017$

- Europe Union promotes mainstreaming of counter-terrorism into EU foreign policy and addressing the nexus of development and security.

- Programming of EU capacity building measures to support counterterrorism efforts in third countries and in coordination with key partners.

The terrorist threat is increasingly diverse and geographically diffuse. It remains significant, complex, and very unpredictable. [European Union External Action, 2016]

The multiple recent terrorist attacks ought to be a warning to the tourism industry that it is entering into a new and dangerous age. In the past, most tourism centres assumed that either they would not be targets of a terrorist attack or that the attack would be against a highly specific and well-known target. It was assumed that we could almost predict which areas would be most prone to terrorism attacks. [Tourism and more, 2016a]

The limitations of the current research are [CBI Ministry of Foreign Affairs, 2016]:

- The determination of risk management strategy:

- There are several strategies for risk management, including: avoiding the risk, reducing the likelihood of the consequences, transferring the risk and retaining the risk.

- Learn from previous crises and disasters that have taken place in your area. Also look into similar crises that have occurred in other areas.

- Risk avoidance:

- This strategy means eliminating the risk by completely avoiding a potentially risky activity.

- Risk reduction:

- If you cannot eliminate a risk, try to reduce it. You can do this by increasing precautions or limiting risky activities as much as possible.

- Risk retention:

- If other strategies are not an option, you will simply have to retain the risk, that is, accept it. This strategy is also common for relatively minor risks that are not severe or do not occur frequently. 

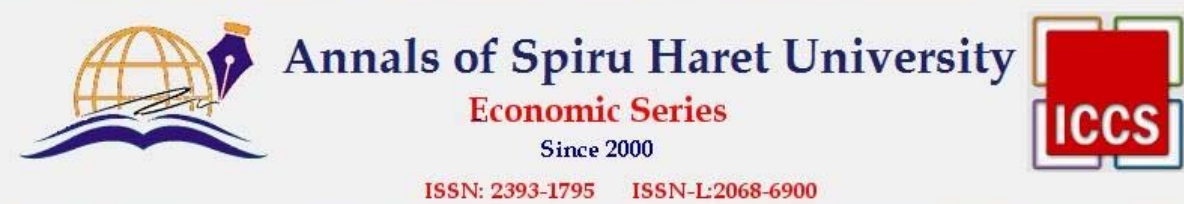

Issue $3 / 2017$

\section{References}

1. CBI Ministry of Foreign Affairs (2016, December 5), "How to manage risks in tourism", CBI Ministry of Foreign Affairs, Retrieved from https://www.cbi.eu/marketinformation/tourism/how-manage-risks-tourism/

2. Campiranon, K., "Factors influencing crisis tourism vulnerability", Academia Edu, Retrieved from http://www.academia.edu/1455659/FACTORS_INFLUENCING_ TOURISM_CRISIS_VULNERABILITY

3. Digi24 (2016, June 30), "Terorismul - amenintare pentru turism", Digi24, Retrieved from http://www.digi24.ro/stiri/externe/mapamond/terorismul-amenintare-pentru-turismcele-mai-periculoase-locuri-din-europa-534215

4. European Council (2017, March 29), "Fight against terrorism". European Council, Retrieved from http://www.consilium.europa.eu/ro/policies/fight-against-terrorism/

5. European Union External Action (2016, May 3), "Counter-terrorism", European Union External Action, Retrieved from https://eeas.europa.eu/headquarters/headquartershomepage/411/counter-terrorism_en

6. Express (2016, July 18), "How safe is your holiday? Mapped: Tourist hotspots with terror threat level now at high", Retrieved from, http://www.express.co.uk/news/ world/587227/Holiday-terror-threat-level-Spain-Tunisia-and-France-on-high-alert

7. Mihalache, G. (2016, July 30), "Atacurile teroriste din Europa", Zf, Retrieved from http://www.zf.ro/business-international/atacurile-teroriste-din-europa-schimba-hartaturistica-a-continentului-care-sunt-cele-mai-periculoase-destinatii-de-vacanta-undese-plaseaza-romania-15544344

8. Opran, C. (2004), Managementul riscului, Course support, Cluj-Napoca.

9. Petroff, A. (2017, March 23), "London tourism terrorism travel", CNN Money, Retrieved from http://money.cnn.com/2017/03/23/news/london-tourism-terrorism-travel/

10. Pizam, A. \& Mansfeld, Y., "Toward a theory of tourism security". In Tourism, security \& safety. From theory to practice, Edited by: Pizam, A. and Mansfeld, Y. (Oxford: Elsevier, 2006), pp. 1-28.

11. The Telegraph (2017, February 20), "Is Turkey safe for tourists and can I cancel my holiday?", Retrieved from http://www.telegraph.co.uk/travel/advice/is-turkey-safefor-tourists/

12. Tourism and more (2002, September), "Risk identity and management", Retrieved from http://www.tourismandmore.com/tidbits/risk-identity-and-management/

13. Tourism and more (2016a, January), "Terrorisms-Aggressive and passive war on tourism", Retrieved from http://www.tourismandmore.com/tidbits/terrorisms-aggressive-andpassive-war-on-tourism/

14. Tourism and more (2016b, July), "July-tourisms trying half month", Retrieved from http://www.tourismandmore.com/tidbits/july-tourisms-trying-half-month/ 


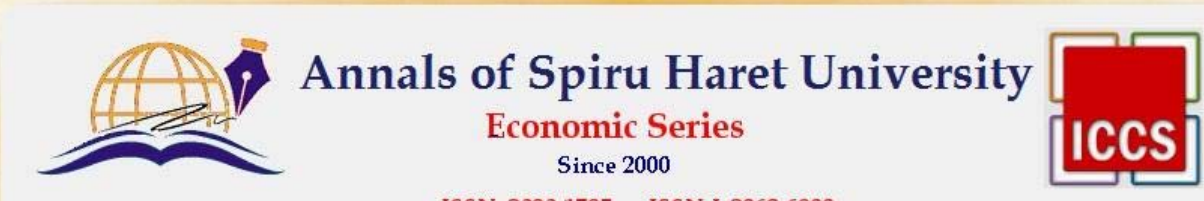

ISSN: 2393-1795 ISSN-L:2068-6900

Issue $3 / 2017$

15. Tourism and more (2016c, October), "Avoiding becoming a tourism or travel victim", Retrieved from http://www.tourismandmore.com/tidbits/avoiding-becoming-a-tourismor-travel-victim/ 